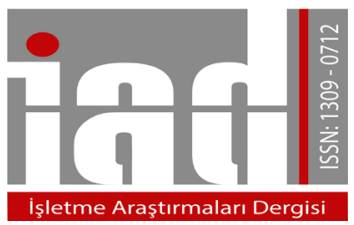

İşletme Araştırmaları Dergisi

Journal of Business Research-Turk

10/4 (2018) 794-806

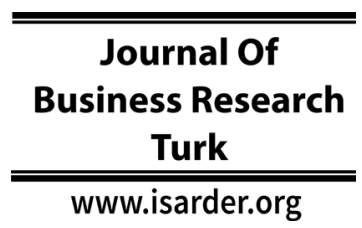

$\underline{\text { Research Article }}$

\title{
An Assessment of the Impact of Employee Satisfaction on Customer Satisfaction in Hotel Enterprises
}

\author{
Oktay EMiR \\ Anadolu University \\ Open Education Faculty \\ Eskisehir, Turkey \\ orcid.org/0000-0002-7972-1980 \\ oktayemir@,anadolu.edu.tr
}

\author{
Sibel ŞAHIN \\ Anadolu University \\ Faculty of Business Administration \\ Eskisehir, Turkey \\ orcid.org/0000-0001-5637-9118 \\ sibel_sahin@anadolu.edu.tr
}

\author{
Yalçın Arslantürk \\ Ankara Hacı Bayram Veli University \\ Tourism Faculty, Ankara, Turkey \\ orcid.org/0000-0003-0936-5391 \\ arslanturk@gazi.edu.tr
}

\begin{abstract}
The aim of this study is to determine the personnel evaluations of employee satisfaction factors in customer satisfaction by using statistical methods. Firstly, the studies about the factors affecting the satisfaction of the employees in the literature were examined and the statements used in the study were formed and then the suitability of the questionnaire in terms of both content and comprehensibility was checked by taking expert opinion. Face to face survey method was used as a method of data collection. Surveys were applied to 419 staff working in international chain hotels in 2017 (September, October, November, December), 2018 (January) between Atlanta, Savannah, Hilton Head Island regions. Statistical analysis was performed with the help of SPSS package program. Variables are described by frequency, percentage, arithmetic mean and standard deviation statistics and also T-test and variance analysis were performed. Tukey test was used for the comparison of binary groups as a result of variance analysis. As a result of the study, it was determined that the most positive opinion of the employees regarding the effect of employee satisfaction on the hotel satisfaction was the terms of working conditions, followed by social rights and communication with the employees, respectively. Moreover, it was determined that the opinions of the participants did not differ significantly according to gender and working position, but for age, marital status, educational status and the department.
\end{abstract}

Keywords: Customer Satisfaction, Employee Satisfaction, Hotel Enterprises

Received 1 October 2018; Received in revised from 7 December 2018; Accepted 10 December 2018 


\section{Introduction}

Studies have shown that satisfied employees are more likely to offer better service and this may result in a satisfactory service experience for their customers. This satisfactory service experience is likely to have a significant impact on the re-visit and retention of the customer. At the same time, studies show that customer retention is likely to increase a company's profitability, for retaining an existing customer is much less costly than attracting new customers (Christina and Gursoy, 2009). Furthermore, studies reveal that employee satisfaction has a significant impact on the consumer service quality customer loyalty, consumer-oriented behaviours, competitive edge, overall operational effectiveness and success, organizational commitment, employee transfer, employee absenteeism, employee success and organizational citizenship behaviour (Kuşluvan and Kuşluvan, 2005). On the other hand, in the studies conducted in the literature related to customer satisfaction, it has been determined that as a result of ensuring customer satisfaction in the enterprises, the profitability of the enterprise increased, more loyal customers were obtained, the products and services produced were purchased by the customers at higher quantity and rate, and customers have a positive mouth-to-mouth advertising behaviour about the business (Olcay and Giritlioğlu, 2014). Therefore, the relationship between customer satisfaction and employee satisfaction, which are two important factors for hotel enterprises, has been taken into consideration in many studies. In this context, studies in the literature are usually conducted in the form of conducting individual questionnaires to employees and customers and then examining the relationship between them. In this study, whether the factors affecting employee satisfaction also affect customer satisfaction was evaluated by taking into consideration the views of the employees. In this respect, the study is expected to give a different perspective to the relevant literature.

\section{The concepts of employee satisfaction and customer satisfaction}

The fact that the tourism sector is labour intensive increases the importance of the workforce in hotels compared to other sectors. In the related literature, employee satisfaction is also conceptualized as job satisfaction and internal customer satisfaction. Employee satisfaction is the emotional response to his / her job as a result of comparisons between the outputs that the employee expectations or desires (Cranny et al., 1992). In another definition, employee satisfaction is expressed as "a satisfying or positive emotional situation that the employee has achieved with his / her assessment of his / her work or experience with his / her work." (Locke, 1976). Demirel et al., (2011) describes employee satisfaction as a degree of satisfaction with the employee's job. It is not possible for an employee who is dissatisfied with his / her work to provide a satisfactory level of service to his / her customer in the hotel business where simultaneous production and consumption are available. To ensure customer satisfaction, employees must also be satisfied with their work and workplaces (Akinc1, 2002). It can be said that satisfied employees are more inclined to be friendly, enthusiastic, attentive and empathetic to customers, so happy employees' behavior plays an important role in shaping the perceptions of customers. In addition, the positive relationship between employee satisfaction and customer service perceptions suggests that employees with higher levels of job satisfaction can provide excellent service. Satisfied employees are expected to be more inclined to share these positive feelings with customers due to the emotional contagion effect, which explains how satisfied employees spread their satisfaction to other people around them (Jeon and Choi, 2012). 
"Total quality management" considers the employees as internal customers based on the idea that an organization that does not take into consideration the needs of employees cannot meet the customer expectations and that it is necessary to satisfy the employees in order to achieve customer satisfaction first. While the satisfaction of the internal customers is important for the healthy functioning of the process and the motivation of the employees, the satisfaction of the external customers is necessary for the existence of the organization (Uryan, 2002).

Studies on job satisfaction in the tourism sector started to gain importance in the 1980s and most of the studies conducted for hotel employees focused on the factors affecting employee satisfaction and the factors affecting the satisfaction of these factors. (Davras and Gülmez 2013:169). Kaya (2007), Davras and Gülmez (2013), İbiş and Batman (2017) conducted research on the factors affecting the satisfaction of the employees in hotel operations in different regions. Studies by Davras and Gülmez (2013) and Ibis and Batman (2017) revealed similar results. They stated that the satisfaction factors of the employees consist of eight dimensions ; colleagues, management style, additional facilities, nature of the work, promotion, wage, reward and communication. In a study Kaya (2007), the factors affecting job satisfaction of employees were identified as communication and integrity, promotion, supervisors, nature of work (non-physical factors), nature of work (physical factors), wage and additional facilities, freedom, management. While there is a production-oriented marketing approach in the early stages of the industry, today the competitive environment is focused on the customer. Increasing competition and decreasing product/service differences have led to the focus of attention on the customer and the emergence of concepts such as customer centrality and customer satisfaction (Demirel et al., 2011). Customer satisfaction is a psychological concept that expresses the feeling or satisfaction of getting what the customer expects or expects from a product or service. Customers with different expectations in the same hotel cannot be expected to be equally satisfied with the service purchased. Therefore, customer satisfaction is not regarded as a universal value (Pizam and Ellis, 1999). Customer satisfaction is the response of the client as a result of all the cognitive and emotional phases that a customer passes through after the use of a product or service (Oliver, 1997). In another definition, customer satisfaction is defined as a psychological concept that occurs as a result of the overlap of the customer's service with the expectation of a product or service (Kotler et al., 1996). Oliver, (1997) defined customer satisfaction as the satisfaction of a product or service as a property or as a satisfaction judgment for itself as a whole, indicating that at least two factors are required to bring about customer satisfaction. One is the output obtained by the use of the product or service and the other is a reference point that can be compared with this result. This reference point can be the perception of satisfaction or satisfaction of people around them from the previous use of the product or service (Oliver, 1997). Taking these factors into consideration, customer satisfaction can be defined as the "judgement" (Szwarc, 2005) based on customers' comparison of certain products or services they have purchased with those offered by the competitors, about which they hear and see. The value given to the concept of customer satisfaction has started to increase with the ever-changing environmental conditions and increasing competition. In addition, it is relatively riskfree for enterprises to retain and retain their existing customers and to enter new markets and gain new customers. Today, where information and technologies can easily be imitated, customer satisfaction as a factor that cannot be easily imitated is seen as an 
important feature that makes a difference between businesses operating in the same sector or companies doing the same job in different sectors (Öz, 2011).

If the customer is satisfied, it will enable potential customers to prefer the business, otherwise it will not prefer the business again, and it will make the business advertisement negatively by transferring the negative situation to others. Therefore, businesses will have the opportunity to get people to promote themselves for free at the same time by providing satisfaction (Szwarc, 2005). In addition, businesses who are interested in whether their customers are satisfied and strive to increase their customer satisfaction levels will sell more products or services and provide more profits (Oliver, 1997).

\section{Literature review}

In the literature review, it was observed that the effect of employee satisfaction on customer satisfaction was taken into consideration in different sectors such as education, bank, stationery and hotel business. The studies and results are given below briefly. Testa et al.(1998) examined whether employee satisfaction and customer satisfaction were related structures in the ship industry. Participants were asked to assess the company's vision and objectives, salary, social rights, working schedule, management style of the manager and the satisfaction level of various business-related factors, including the ship. Among these factors, the factors such as the company's vision and objectives, employee welfare and professional development anxiety are the most important contributors to job satisfaction and ultimately to customer satisfaction. As a result, it was empirically confirmed that these were related structures in the ship industry and that employee satisfaction directly affects customer satisfaction.

In order to determine employee and customer satisfaction factors in the bank sector and to examine the effects of employee satisfaction on customer satisfaction, the study found that employees ' satisfaction from wage-reward-promotion, organizational practices-working environment and ergonomic conditions was associated with customer satisfaction. In addition, the increase in the satisfaction levels of employees regarding learning/education, commitment and social/solidarity factors did not affect the overall level of satisfaction of the customers to a statistically significant extent (Naktiyok and Küçük, 2003). In a graduate study conducted over the employees and customers of a stationery company, it was determined that there was a significant relationship between internal customer satisfaction and external customer satisfaction and that there was an increase in external customer satisfaction level as the level of internal customer satisfaction increased (Karadeniz, 2013). Christina and Gürsoy (2009) found that there is a direct relationship between customer satisfaction and employee satisfaction in five destinations, three and four star hotel employees and their customers.

Customer satisfaction and employee satisfaction are considered as two determinant factors in raising financial performance and employee satisfaction has been found to be effective on customer satisfaction (Demirel et al., 2011). In a study conducted in one of Korea's leading private education companies, it was investigated whether the relationship between employee satisfaction and customer satisfaction is double-sided or single-sided based on bilateral data. The results show that employee satisfaction leads to customer satisfaction, but customer satisfaction does not affect employee satisfaction, and therefore the relationship between employee satisfaction and customer satisfaction is unilateral rather than bilateral (Jeon and Choi 2012). Spinelli and Canavos, (2000) concluded that there was a positive relationship between employee 
satisfaction and customer satisfaction. In another study, the relationship between employee satisfaction and customer satisfaction was examined, there was a significant relationship between the two variables. In addition, it was determined that employee satisfaction had a positive effect on customer satisfaction (Ulamış, 2004). In the study, the relationship between employee satisfaction and customer satisfaction in five and four star hotels in the kingdom of Bahrain, the findings were determined that employee satisfaction is one of the important determinants of employee satisfaction because of the unforgettable experience that employees will face with employee satisfaction if they exceed their expectations (Atteia, 2016).

\section{Methodology}

The survey method was used as a data collection tool. In the first part of the questionnaire, there are six questions related to demographic characteristics, while in the second part of the questionnaire there are sixteen judgements that measure employee evaluations for the impact of the business atmosphere on customer satisfaction. These judgments were rated as "Strongly agree " $=5$ and "Strongly Disagree" $=1$ with a Likert type scale of 5 .these judgments were rated as "Strongly Disagree" $=5$ and "strongly Disagree" $=1$. The second part of the survey, which is used in the survey, was created by examining the previous studies on the subject (Kong et al., 2009; Magablih and Al Shiab, 2009; Gallardo et al., 2010; Davras and Gülmez, 2013; Cruz et al., 2014; Akova et al., 2015; Azic, 2017; Kong et al., 2018) and the suitability of the survey in terms of content and comprehensibility was controlled by taking the opinion of the expert. Cronbach's Alpha coefficient for the internal consistency of the sixteen item scale was calculated as 0.911 . The study population consisted of 419 staff working in international chain hotels in the regions of Atlanta, Savannah and Hilton Head Island between 2017 (September, October, November, December) and 2018 (January). Statistical analysis was carried out with the help of SPSS package program. The variables were described by frequency, percentage, arithmetic mean and standard deviation statistics. In addition, since the analysis met the conditions for parametric test assumptions (normal distribution, homogeneity of variances, number of individuals in each group etc.), $t$ test was performed if there were two independent groups, and variance analysis were performed in the case of three independent groups. Tukey test was used for the comparison of binary groups as a result of variance analysis.

\section{Findings}

Table 1 presents the frequency and percentage distributions of the individual characteristics of a total of 419 participants. Accordingly, it was determined that $40.3 \%$ of the participants were women and $59.7 \%$ were men. Of the participants, $13.6 \%$ belong to the age group 24 and below, $30.5 \%$ to $25-34,35.3 \%$ to $35-44$ and $20.5 \%$ to 45 and over. When the distribution of the participants according to their marital status is examined, it is seen that $52.7 \%$ is single and $47.3 \%$ is married. The distribution of the participants according to their educational status revealed that $46.3 \%$ were Bachelor's, $40.6 \%$ high school, $6.4 \%$ graduate, $5.0 \%$ undergraduate and $1.7 \%$ had other levels of Education. $37.5 \%$ of the participants have stated that they work in the departments of $\mathrm{F}$ \& B, 22.4\% front office, $11.7 \%$ housekeeping, $7.9 \%$ technical services, $4.8 \%$ human resources, $4.8 \%$ accounting, 5\% marketing and sales, and $5.7 \%$ other (spa, security etc.) departments. On the other hand, $17.2 \%$ of the participants stated that they were managers and $82.8 \%$ of them were employed as employees. It is observed that many of the participants were concentrated between the ages of 25-44 and that the majority were 
single and university-level education and the number of employees in the food and drink department was higher. This distribution of the individual characteristics of the participants reflects the characteristics of the hotel industry. Especially labour intensive manpower is highly needed. We can say that the reason for the intensive employment of young and middle age groups is due to the need for labour force. In addition, the majority of employees are graduates of the University, which is an important part of the employment of those who have been educated in tourism as well as higher education levels. Another striking point is that employment is concentrated in the food and drink section, for the area allocated to food and beverage services in the hotel industry is both wide and varied features and alternative services are also offered. Therefore, employees in food and drink departments have different characteristics in terms of both quality and quantity.

Table I: Distribution of Participants by Individual Characteristics

\begin{tabular}{|c|c|c|c|}
\hline Variable & Group & $\mathbf{n}$ & $\%$ \\
\hline \multirow[t]{2}{*}{ Gender } & Female & 169 & 40,3 \\
\hline & Male & 250 & 59,7 \\
\hline \multirow[t]{4}{*}{ Age } & $24-$ & 57 & 13,6 \\
\hline & $25-34$ & 128 & 30,5 \\
\hline & $35-44$ & 148 & 35,3 \\
\hline & $45+$ & 86 & 20,5 \\
\hline \multirow[t]{2}{*}{ Marital Status } & Single & 221 & 52,7 \\
\hline & Married & 198 & 47,3 \\
\hline \multirow[t]{5}{*}{ Education } & High School & 170 & 40,6 \\
\hline & Bachelor's & 194 & 46,3 \\
\hline & Undergraduate & 21 & 5,0 \\
\hline & Graduate & 27 & 6,4 \\
\hline & Other & 7 & 1,7 \\
\hline \multirow[t]{8}{*}{ Department } & Front office & 94 & 22,4 \\
\hline & Food and Beverage & 157 & 37,5 \\
\hline & Housekeeping & 49 & 11,7 \\
\hline & Human Resources & 20 & 4,8 \\
\hline & Maintenance & 33 & 7,9 \\
\hline & Accounting & 20 & 4,8 \\
\hline & Sales and marketing & 22 & 5,3 \\
\hline & Other (spa, sec., etc.) & 24 & 5,7 \\
\hline \multirow[t]{2}{*}{ Position } & Manager & 72 & 17,2 \\
\hline & Employee & 347 & 82,8 \\
\hline \multicolumn{2}{|l|}{ Total } & 419 & 100,0 \\
\hline
\end{tabular}

The descriptive statistics for determining the personnel assessments for the impact of the business atmosphere on customer satisfaction in hotel enterprises are presented in Table 2. The sixteen-point scale was rated as a 5-point Likert type and was rated as "strongly agree" $=5$ and "strong disagree" $=1$. The negative items "my relationship with management does not affect customer satisfaction" and "My working environment does 
not affect customer satisfaction " are reversed-coded. When the statistics were analysed in Table 2, it was found that the mean value of all items was close to or higher than 4 . It is seen that "My working conditions affect customer satisfaction" $(\bar{X}=4,56)$ is the most positive view for the impact of the business atmosphere on customer satisfaction in hotel enterprises and $67.8 \%$ of the participants stated positive views with the of "strongly agree" and $23.6 \%$ of the participants with "agree". Employee is the most important value of the hotel business. They are the hotel staff who offer the business values to the customer and make them feel valued. In this regard, the working conditions of hotel employees should be regularly monitored and improved. Improving the working conditions will increase the efficiency of the employee as well as the employee's job satisfaction by ensuring that the employee is valued.

On the other hand, participants expressed a higher level of positive feedback to "my adequate social rights affect customer satisfaction" $(\bar{X}=4,53)$, and "my communication with employees affect customer satisfaction". It is also the responsibility of the hotel management to think about the aspects of the employees and to make improvements in this regard. It is an important issue for employees to have and maintain social rights. Because the protection of the future and the working conditions in the present work will make you psychologically comfortable. It is impossible to expect a productive job from an employee who is not psychologically comfortable. For this reason, the social life quality of employees should be continuously improved and they should be felt by the governments they are an important part of the organizational structure. This result shows that manpower is an important factor in hotel businesses. In addition, each hotel Department employee is a customer of each other, and achieving the targeted service quality depends on the success of the communication between departments and employees. It is seen that the relations with management and the employees of the working environment play an important role in the questions asked in the two questions that are coded as a distractor and reverse coded. The views of the participants on these items are explained in the on-going sentences.

For the items "My relationship with management does not affect customer satisfaction" ( $\overline{\mathrm{X}}=2,43)$, it is seen that $16.9 \%$ of the participants stated "strongly disagree 'and 49.4\% "disagree". The realization of the relationship between the manager and employees with a collaborative and collaborative management approach leads to an increase in employee satisfaction. Giving importance to the ideas of the employee causes the employee to take ownership of the job and positively affect the satisfaction of the job. For the item "My working environment does not affect customer satisfaction" ( $\bar{X}=2,42), 20.5 \%$ of the participants stated "strongly disagree" and $44.6 \%$ "disagree". The opinions of the staff that are considered to be less effective (less negative) for the effect of business atmosphere on customer satisfaction in hotel enterprises are the items "My physical facilities affect customer satisfaction" ( $\bar{X}=3,95)$, "Demonstrating tolerance to management mistakes affects customer satisfaction" ( $\bar{X}$ $=4,00$ ), and "My fear of losing job affects customer satisfaction" My fear of losing job affects customer satisfaction" $(\bar{X}=4,02)$. It is seen that Physical conditions, management's tolerance to employee errors, and fear of losing jobs are less effective on the satisfaction of hotel employees, that is, it is less important for employees than other issues. In fact, we can say that the item of improvement of working conditions expresses the general expectations of employees. Many wishes and desires reveal that 
there is a latent expectation of employees under this thought. Another thought might be that social, economic, and physical conditions are well thought out in the enterprises that give importance to their employees.

In addition, hotel staff showed less positive views than others for the items "Appreciating by customers affects customer satisfaction" ( $\overline{\mathrm{X}}=4,08)$, “Appreciating by the management affects customer satisfaction" $(\bar{X}=4,11)$, "Attaching importance to my ideas by hotel management affects customer satisfaction" ( $\bar{X}=4,11)$ and "Management's ethical behaviour against me affects customer satisfaction" $(\bar{X}=4,13)$.

Table II: opinions of employees on the impact of business atmosphere on customer satisfaction in Hotel Enterprises

\begin{tabular}{|c|c|c|c|c|c|c|c|}
\hline \multirow[t]{2}{*}{ ITE } & 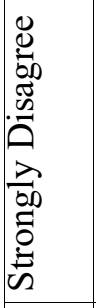 & 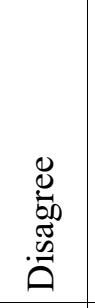 & 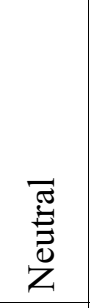 & 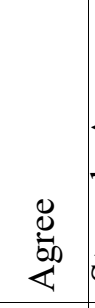 & 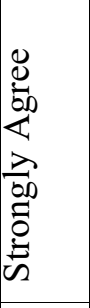 & \multirow[b]{2}{*}{$\bar{X}$} & \multirow[b]{2}{*}{ SS } \\
\hline & $\%$ & $\%$ & $\%$ & $\%$ & $\%$ & & \\
\hline My adequate social rights affect customer satisfaction & 0,7 & 2,6 & 6,2 & 23,4 & 67,1 & 4,53 & 0,79 \\
\hline My working conditions affect customer satisfaction & 0,2 & 2,6 & 5,7 & 23,6 & 67,8 & 4,56 & 0,74 \\
\hline $\begin{array}{l}\text { My communication with employees affects customer } \\
\text { satisfaction }\end{array}$ & 0,2 & 2,9 & 7,6 & 28,4 & 60,9 & 4,47 & 0,78 \\
\hline $\begin{array}{l}\text { Management being fair to me affects customer } \\
\text { satisfaction }\end{array}$ & 0,2 & 4,5 & 9,8 & 35,6 & 49,9 & 4,30 & 0,84 \\
\hline The wage I get affects customer satisfaction & 1,9 & 3,6 & 9,8 & 38,7 & 46,1 & 4,23 & 0,91 \\
\hline $\begin{array}{l}\text { Customer attitudes towards me affect customer } \\
\text { satisfaction }\end{array}$ & 0,7 & 4,3 & 10,5 & 46,8 & 37,7 & 4,16 & 0,83 \\
\hline $\begin{array}{l}\text { Management's ethical behaviour against me affects } \\
\text { customer satisfaction }\end{array}$ & 1,2 & 3,8 & 11,0 & 48,7 & 35,3 & 4,13 & 0,84 \\
\hline $\begin{array}{l}\text { My relationship with management does not affect } \\
\text { customer satisfaction }\end{array}$ & 16,9 & 49,4 & 14,6 & 11,9 & 7,2 & 2,43 & 1,12 \\
\hline My physical facilities affect customer satisfaction & 3,1 & 7,7 & 14,3 & 39,9 & 35,0 & 3,95 & 0,80 \\
\hline $\begin{array}{l}\text { My working environment does not affect customer } \\
\text { satisfaction }\end{array}$ & 20,5 & 44,6 & 13,4 & 14,8 & 6,7 & 2,42 & 1,16 \\
\hline $\begin{array}{l}\text { Appreciating by customers affects customer } \\
\text { satisfaction }\end{array}$ & 0,2 & 5,5 & 14,3 & 45,6 & 34,4 & 4,08 & 0,85 \\
\hline $\begin{array}{l}\text { Appreciating by the management affects customer } \\
\text { satisfaction }\end{array}$ & 0,7 & 5,5 & 15,5 & 38,2 & 40,1 & 4,11 & 0,91 \\
\hline My fear of losing job affects customer satisfaction & 0,7 & 4,5 & 14,8 & 55,4 & 24,6 & 4,02 & 1,01 \\
\hline $\begin{array}{l}\text { Demonstrating tolerance to management mistakes } \\
\text { affects customer satisfaction }\end{array}$ & 1,4 & 9,5 & 12,4 & 41,8 & 34,8 & 4,00 & 0,99 \\
\hline
\end{tabular}




\begin{tabular}{|l|l|l|l|l|l|l|l|}
\hline $\begin{array}{l}\text { Attaching importance to my ideas by hotel } 1,2 \\
\text { management affects customer satisfaction }\end{array}$ & 6,9 & 13,1 & 37,7 & 41,1 & 4,11 & 0,96 \\
\hline $\begin{array}{l}\text { Being considered important by the teammates affects } 1,4 \\
\text { customer satisfaction }\end{array}$ & 5,0 & 12,2 & 37,2 & 44,2 & 4,18 & 0,93 \\
\hline
\end{tabular}

Table 3 presents the results of t-test and variance analysis for the comparison of personnel opinions with respect to individual characteristics for the effect of employee satisfaction on customer satisfaction in hotel enterprises. According to this, the participants ' opinions were determined to differ significantly from the gender and the working position $(\mathrm{p}>0.05)$, while the age, marital status, educational status and the working department were determined to differ significantly $(p<0.05)$. According to this situation, the participants under the age of 24 years and under $(\bar{X}=3,81)$ declared that the employee satisfaction effect was not high in customer satisfaction. First of all, it is not possible to say that the people under the age of 24 have a lot of work experience. Hotel management is based on experience and experience. You have to satisfy unlimited customer wishes and desires with limited resources. As the staff experience increases, the ability to understand and interpret the issues will develop. In addition, according to the marital status of the employee satisfaction effect, the average values of the marital status of the married $(\bar{X}=4,23)$ compared to the singles $(\bar{X}=4,03)$ were found to be more positive. We can say that married individuals approach the events more optimistic and warm. In other words, we can say that the awareness and sensitivities of married individuals are better.

Another remarkable point in the study is that those with bachelor's ( $\bar{X}=4,21)$ education have the most positive opinion and those with a graduate $(\bar{X}=3,80)$ level have the most negative opinion. As the level of education increases, the expectations of individuals change. Therefore, those with high levels of education will have higher levels of awareness at the point of analysing and evaluating the events. It is also observed in the study that there will be variations in the opinions and expectations of individuals as they reach higher levels of Education. We can say that there is a linear ratio between the opinions of individuals in each training group and the educational level. Whether or not Hotel enterprises are aware of this situation is an important issue.

In addition, when the arithmetic mean values of employees are examined according to the department they work for the effect of employee satisfaction on customer satisfaction, "human resources" $(\bar{X}=4,40)$ employees have expressed their views in the most positive "housekeeping services" $(\bar{X}=3,83)$ and employees have expressed their views in the most negative way. It is natural for human resources department to provide a positive opinion at the highest value due to the fact that they provide personnel to the hotel enterprises and they are a department that follows the development and other operations of these employees. As part of the duty field, it is in close contact with the staff and the department that knows them best. Therefore, the fact that employee satisfaction expresses customer satisfaction is important in terms of the reliability and results of this research. Housekeeping employees are generally a department that does business based on both body and machine power. This department is concerned with the detailed details of the cleaning and is responsible for many departments of the hotel business. In general, it is known that the level of education of the employees in this department is lower than the level of education of other 
department employees. In this section, cleaning-based jobs are done in general, even after a certain level of education without a high level of Education individuals can work in this department. In this respect, it is not surprising that the expectations and opinions of the employees of this department regarding the business atmosphere are low.

Table III: Comparison of Participant Opinions According to Socio-Demographic Characteristics

\begin{tabular}{|c|c|c|c|c|c|}
\hline Variable & Group & $\overline{\mathrm{X}}$ & SS & $t / F$ & $\mathbf{p}$ \\
\hline \multirow[t]{2}{*}{ Gender } & Female & 4,11 & 0,58 & \multirow[t]{2}{*}{0,259} & \multirow[t]{2}{*}{0,796} \\
\hline & Male & 4,13 & 0,60 & & \\
\hline \multirow[t]{4}{*}{ Age } & $24-$ & $3,81 \mathrm{~b}$ & 0,70 & \multirow[t]{4}{*}{6,478} & \multirow[t]{4}{*}{$0,000^{*}$} \\
\hline & $25-34$ & $4,15 \mathrm{a}$ & 0,50 & & \\
\hline & $35-44$ & $4,19 a$ & 0,55 & & \\
\hline & $45+$ & $4,16 a$ & 0,65 & & \\
\hline \multirow[t]{2}{*}{ Marital Status } & Single & 4,03 & 0,64 & \multirow[t]{2}{*}{3,536} & \multirow[t]{2}{*}{0,000} \\
\hline & Married & 4,23 & 0,51 & & \\
\hline \multirow[t]{5}{*}{ Education } & High School & $4,09 \mathrm{~b}$ & 0,69 & \multirow[t]{5}{*}{3,593} & \multirow[t]{5}{*}{$0,007^{\prime \prime}$} \\
\hline & Bachelor's & $4,21 \mathrm{a}$ & 0,48 & & \\
\hline & Undergraduate & $4,08 \mathrm{~b}$ & 0,53 & & \\
\hline & Graduate & $3,80 \mathrm{c}$ & 0,64 & & \\
\hline & Other & $3,84 \mathrm{c}$ & 0,28 & & \\
\hline \multirow[t]{8}{*}{ Department } & Front office & $4,20 b$ & 0,54 & \multirow[t]{8}{*}{3,594} & \multirow[t]{8}{*}{$0,001^{\prime \prime}$} \\
\hline & Food and Beverage & $4,14 b$ & 0,56 & & \\
\hline & Housekeeping & $3,83 c$ & 0,65 & & \\
\hline & Human Resources & $4,40 \mathrm{a}$ & 0,49 & & \\
\hline & Maintenance & $3,99 \mathrm{c}$ & 0,75 & & \\
\hline & Accounting & $4,26 \mathrm{~b}$ & 0,41 & & \\
\hline & $\begin{array}{ll}\text { Sales and } \\
\text { marketing }\end{array}$ & $4,27 b$ & 0,58 & & \\
\hline & $\begin{array}{l}\text { Other (spa, sec., } \\
\text { etc.) }\end{array}$ & $3,96 \mathrm{c}$ & 0,59 & & \\
\hline \multirow[t]{2}{*}{ Position } & Manager & 4,11 & 0,56 & \multirow[t]{2}{*}{0,220} & \multirow[t]{2}{*}{0,826} \\
\hline & Employee & 4,12 & 0,60 & & \\
\hline
\end{tabular}

${ }^{*} p<0,01$ a,b,c: different letters indicate differences between groups.

\section{Conclusions and Implications}

In this study, in which the effect of employee satisfaction on customer satisfaction is evaluated with employee opinions, it is seen that the most effective factors affecting customer satisfaction are social rights, working conditions and communication with employees. It was determined that physical facilities, management tolerance and fear of losing job were least effective in customer satisfaction.

While there is no significant difference in terms of gender and working position variables in comparing the effect of employee satisfaction on customer satisfaction according to socio-demographic characteristics, there were significant differences in terms of age, marital status, educational status and department of study department. Employees under the age of twenty-five are to other age groups; if they are single, they think that employee satisfaction is less effective than customer. While employees of the 
department who have the opinion that the effect of employee satisfaction on customer satisfaction is higher, being human resources, it was the housekeeping staff who had the opinion that they were least effective.

The limitations of this study are that the study is conducted with a limited number of samples in a limited area of the hotel. In this respect, it would be useful to work with larger sample groups.

\section{Acknowledgements}

We would like to express our gratitude to Project Department of Anadolu University and the staff for their support and contribution (Project No: 1705E354).

\section{References}

Akıncı, Z. (2002). Turizm Sektöründe İşgören Tatminini Etkileyen Faktörler: Beş Yıldızlı Konaklama İşletmelerinde Bir Uygulama, Akdeniz Üniversitesi İ.I.B.F. Dergisi, 4, 1-25.

Akova, O., Emiroğlu, D.B., Tanrıverdi, H. (2015). Satisfaction and Turnover Intent: A Study at Five Star Hotels in Istanbul, Journal of Management, Marketing and Logistics, 2(4), 378-402.

Atteia, M. (2016). Employees' Satisfaction Is It an Antecedent of Customers' Satisfaction: An Empirical Study on the Five and Four Star Hotels in the Kingdom of Bahrain. Journal of Marketing and Consumer Research. 22, 103-114

Azic, L.M. (2017). The Impact of Hotel Employee Satisfaction on Hospitability Performance, Tourism and Hospitality Management, 23(1), 105-117.

Christina G., Gürsoy, D. (2009). Employee Satisfaction, Customer Satisfaction, and Financial Performance: An Empirical Examination. International Journal of Hospitality Management. 28, 245-253.

Cranny, C.L., Smith, P., Stone, F.F. (1992). Job Satisfaction: How People Feel About Their Job and How It Affects Their Performance . Lexington Books, Newyork.

Cruz, S.G.F., Guzman, L.T., Canizares, S.M.S. (2014). Analysis of Job Satisfaction in the Hotel Industry: A Study of Hotels in Spain, Journal of Human Resources in Hospitality \& Tourism, 13, 63-80.

Davras, Ö., Gülmez, M. (2013). Otel İşletmelerinde Çalışan Memnuniyetine Etki Eden Faktörler: Kemer-Lara-Belek-Side-Alanya Bölgelerinde Bir Çalışma, Anatolia: Turizm Araştırmaları Dergisi, 24(2), 167-184.

Demirel, E. T., Uluyol, O., Derin, N. (2011). Finansal Performansin Yükseltilmesinde İki Belirleyici Faktör: Müşteri Memnuniyeti Ve Çalışan Tatmini: Malatya'da Faaliyet Gösteren Süpermarketlerde Bir Uygulama. Adıyaman Üniversitesi Sosyal Bilimler Enstitüsü Dergisi, 4(7), 315-336 
Gallardo, E., Sanchez-Canizares, M.S., Lopez-Guzman, T., Jesus, N.M.M. (2010). Employee Satisfaction in the Iberian Hotel Industry The case of Andalusia (Spain) and the Algarve (Portugal), International Journal of Contemporary Hospitality Management, 22(3), 321-334.

İbiş, S., Batman, O. (2017). Otel İşletmelerinde Çalışanların Memnuniyetine Etki Eden Faktörler Üzerine Bir Araştırma, Journal of Tourism and Gastronomy Studies, 5(4), 264-279.

Jeon, H., Choi, B. (2012). The Relationship Between Employee Satisfaction and Customer Satisfaction, Journal of Services Marketing, 26(5), 332-341.

Karadeniz, S. (2013). İç müşteri memnuniyetinin dış müşteri memnuniyetine etkileri ve bir araştırma. (Unpublished Master's Thesis). İstanbul Arel Üniversitesi Sosyal Bilimler Enstitüsü, İstanbul.

Kaya, İ. (2007). Otel İsletmeleri İşgörenlerinin İş Tatminini Etkileyen Faktörler: Geliştirilen bir iş tatmini ölçeği, Anadolu Üniversitesi Sosyal Bilimler Dergisi, 27(2), 355-372.

Kong, H., Jiang, V., Chan, W., Zhou, X. (2018). Job Satisfaction Research In The Field of Hospitality And Tourism, International Journal of Contemporary Hospitality Management, 30(5), 2178-2194.

Kong, H.,Baum, T., Cheung, C. (2009). A comparative study of the job perceptions of hospitality and tourism staff in China, https://scholarworks.umass.edu/ cgi/viewcontent.cgi?article=1478\& context $=$ ttra, (E. T. 09.10.2018).

Kotler, P., Bowen, J.,Makens, J. (1996). Marketing for Hospitality and Tourism. Upper Saddle River, NJ: Prentice Hall.

Kuşluvan, Z., Kuşluvan, S. (2005). Otel İşletmelerinde İş ve İşletme ile İlgili Faktörlerin İş̧gören Tatmini Üzerindeki Görece Etkisi: Nevşehir Örneği. Anatolia: Turizm Arastirmalari Dergisi, 16(2). 183-203

Locke, E.A. (1976). The Nature and Consequences of Job Satisfaction. In: Dunnette, M.D. (Ed) Handbook of Industrial Organizational Psychology, IL: Rand McNally, Chicago, 1297-1349.

Magablih, K., Al Shiab, A. (2009). The Implications of Hotel Employee Satisfaction in Promoting Quality Tourism at the Cultural Heritage Site of Petra-Jordan, TEAM Journal of Hospitality \& Tourism, 6(1), 36-45.

Naktiyok, A., Küçük, O. (2003). İşgören (İç Müşteri) ve Müşteri (Dış Müşteri) Tatmini, İşgören Tatmininin Müşteri Tatmini Üzerine Etkileri: Ampirik Bir Değerlendirme. Atatürk Üniversitesi İktisadi ve İdari Bilimler Dergisi, 17(1-2). 225-243.

Olcay, A., Giritlioğlu, İ. (2014). Gaziantep Bölgesinde Şehir Turizmine Hizmet Veren Otellerde Müşteri Memnuniyeti Üzerine Bir Araştırma. Elektronik Sosyal Bilimler Dergisi, 13(50), 1-22.

Oliver, R L. (1997). Satisfaction: A Behavioral Perspective on the Consumer. Boston, MA: Irwin, McGraw-Hill. 
Öz, M. (2011). İş Hayatında Başarının İki Temel Koşulu: Tüketici Davranışlarını Anlayabilmek ve Müşteri Memnuniyetini Sağlamak, International Journal of Social and Economic Sciences, 1(2), 95-99,

Pizam, A., Ellis, T. (1999). Customer Satisfaction and Its Measurement in Hospitality Enterprises, International Journal of Contemporary Hospitality Management, 11(7), 326-339

Spinelli, M.A., Canavos, G. C. (2000). Investigating the Relationship between Employee Satisfaction and Guest Satisfaction. Cornell Hotel and Restaurant Administration Quarterly, 41(6), 29-33.

Szwarc, P. (2005). Researching Customer Satisfaction \& Loyalty: How to Find Out What People Really Think, London: Kogan Page.

Testa, M.R., Skaruppa, C., Pietrzak, D. (1998). Linking job satisfaction and customer satisfaction in the cruise industry: implications for hospitality and travel organizations. Journal of Hospitality \& Tourism Research, 22(1), 4-14.

Ulamış A.Ç. (2004). İşgören Tatmini ile Müşteri Tatmini Arasındaki İlişki ve Bu İlişkiyi Etkileyen Faktörler: 5 Yıldızlı Otellerde Bir Uyguluma, (Unpublished Master's Thesis), Hacettepe Üniversitesi Sosyal Bilimler Enstitüsü, Ankara.

Uryan, B. (2002). Toplam Kalite Yönetimi. Mevzuat Dergisi, 5(55). https://www.mevzuat dergisi.com/2002/07a/02.htm (24.10.2018). 